\title{
An assessment of the freshwater natural capital in KwaZulu-Natal for conservation planning
}

\author{
NA Rivers-Moore*, PS Goodman and MR Nkosi \\ Ezemvelo KZN Wildlife, PO Box 13053, Cascades 3202, South Africa
}

\begin{abstract}
Freshwater conservation planning, while lagging behind terrestrial conservation planning, is beginning to be implemented in a complementary manner to the latter. Ezemvelo KZN Wildlife is currently preparing an aquatic conservation plan for the freshwater systems of KwaZulu-Natal. The development of a freshwater conservation plan requires an initial understanding of the broad characteristics of the resource and associated biodiversity. Within KwaZulu-Natal, which is water-rich relative to the remaining provinces in South Africa, there are approximately 585000 ha of mapped freshwater wetlands, $17 \%$ of which fall within protected areas. At the 1:500 000 scale, there are in excess of $18400 \mathrm{~km}$ of perennial and ephemeral rivers mapped, and just over $1000 \mathrm{~km}(5.6 \%)$ of these fall within existing formal protected areas. The river systems feed into 79 estuaries covering a mapped area of over 30600 ha, of which $41 \%$ amounting to almost 12400 ha are found largely within protected areas, although this does not reflect the actual number protected. These freshwater resources provide over $28 \%$ of South Africa's total average MAR. Protection of this resource requires the protection of freshwater biodiversity, and the processes which maintain these ecosystems. Currently the greatest threats to this resource are river regulation and land transformation.
\end{abstract}

Keywords: KwaZulu-Natal, freshwater resource assessment, aquatic diversity, freshwater conservation planning

\section{Introduction}

Freshwater stress occurs when water withdrawals exceed availability. According to this criterion, and based on global-scale assessments, the east coast of South Africa is one of the few regions nationally to experience low water stress, while the remainder of the country is under 'severe water stress' (withdrawals-to-availability ratio $>0.4$ ) (Alcamo and Henrichs, 2002). One possible scenario under anticipated global climate changes within the next 30 years $\left(0.2\right.$ to $0.3^{\circ} \mathrm{C}$ increase in air temperature per decade; Alcamo et al. 2003) is 'business-asusual', where market and population growth continue along their current trajectories. This scenario indicates that because of increasing water withdrawals, water stress is likely to continue in large parts of South Africa (Alcamo et al., 2003). These scenarios do not take into account pressure on aquatic ecosystems and impacts on water quality, associated with increasing land transformation known to be occurring within KwaZulu-Natal (Alcamo et al., 2003; Goodman 2006, unpublished data)

While KwaZulu-Natal is the only province in South Africa which can truly be described as not being water scarce under current or possible future climatic conditions, appropriate stewardship of the province's freshwater resources will only be achieved through forward-looking conservation planning. The relative robustness of KwaZulu-Natal to climate change could provide added incentive to the formulation and implementation of an appropriate freshwater conservation plan. Since administrative boundaries largely follow hydrological boundaries-escarpment

* To whom all correspondence should be addressed.

or +2733-8451429; fax: +2733-8451226;

e-mail: riversmn@kznwildlife.com

Received 11 January 2007; accepted in revised form 27 July 2007. in the west, and draining to the sea in the east - management of freshwater resources becomes a largely regional, provincial mandate, without dependence on upstream influence.

The link between ecological integrity of water resources and their continued provision of ecosystem goods and services to burgeoning populations is well recognised (Millennium Ecosystem Assessment 2005a, b). A strong legislative framework which backs up South Africa's obligations to numerous international conservation agreements creates the necessary enabling legal framework for the protection of freshwater resources. A key international conservation agreement signed by South Africa is the Convention on Biological Diversity (1994), with South Africa's response being the National Spatial Biodiversity Assessment (NSBA) (DEAT, 2005), and the National Biodiversity Strategy and Action Plan (NBSAP) (Driver et al., 2005). National enabling legislation recently promulgated includes the Biodiversity Act (2004) and the Protected Areas Act (2003), both of which grew out of the over-arching National Environmental Management Act (1998) (Roux et al., 2006). Based on these agreements and legislation, each province in South Africa is required to produce environmental management plans (Driver et al., 2005). However, a necessary step which precedes any systematic conservation planning of freshwater resources is to describe and catalogue the resources (and in this case freshwater resources) which require management and protection.

Landscape-level descriptions of freshwater assets range from descriptive metrics (river length and drainage density), to more detailed assessments such as water-yield maps. Of increasing importance to conservation planning, because of their significance as reference systems, are free-flowing rivers, which are defined as 'any river that flows undisturbed from its source to its mouth, either at the coast, an inland sea or at the confluence with a larger river, without encountering any dams, canalisation, weirs or barrages and without being hemmed in by dykes or 


\begin{tabular}{|l|l|l|}
\hline \multicolumn{3}{|c|}{ TABLE 1 } \\
\hline Coverage & Mapping scale & Source \\
\hline Biogeographic regions & $1: 50000$ & Eekhout et al. (1997); EKZNW (2007) \\
\hline Rivers & $1: 500000$ & DWAF (2005) \\
\hline Rivers & $1: 250000$ & Chief Directorate: Surveys and Mapping \\
\hline Rivers & $1: 50000$ & Chief Directorate: Surveys and Mapping \\
\hline Estuaries & $1: 10000$ & EKZNW (2001) \\
\hline Wetlands & $1: 250000$ & EKZNW (2002) \\
\hline Protected areas & $1: 50000$ & EKZNW (2007) \\
\hline KZN dams & $1: 50000$ & Chief Directorate: Surveys and Mapping \\
\hline KZN primary catchments & N/A & EKZNW (2007) \\
\hline Topo-cadastral map sheets & $1: 50000$ & Chief Directorate: Surveys and Mapping \\
\hline 200m Digital elevation model (DEM) & $1: 50000$ & Computamaps (2001) \\
\hline Median monthly rainfall (x12) & $200 \mathrm{~m}$ & Schulze (2006) \\
\hline Average monthly crop evapotranspiration (x12) & $200 \mathrm{~m}$ & Schulze (2006) \\
\hline
\end{tabular}

levees' (WWF, 2006). The aim of this paper is twofold - firstly, to provide a broad description of the freshwater assets within KwaZulu-Natal, including wetlands and estuaries, and highlight key biodiversity issues pertinent to this resource (which adds weight to its urgent need for conservation); and secondly, to highlight future steps required in developing a freshwater conservation plan for KwaZulu-Natal.

\section{Methods}

The entire KwaZulu-Natal Province was selected as the study area for freshwater resource analyses. Freshwater resources considered important in these analyses include broad descriptions of species numbers and levels of endemism, and hydrological descriptors (river lengths, areas of wetlands and estuaries, areas of high water yield). Enumeration of the freshwater resources of the province was based on analyses of geographical data obtained through queries of GIS coverages (Table 1), and interrogation of relevant databases.

\section{Biological resources}

A basic audit of the freshwater biodiversity assets was undertaken for freshwater fish and amphibians (number of species, and number of endemic species), as well as dragonflies and damselflies (Odonata). The biodiversity database created and maintained by EKZNW was queried for these data at quarterdegree precision. Information on bird species associated with freshwater systems was also included, but could not be gathered through database queries in the same way as the abovementioned taxa because of the relative mobility of individuals. Instead, key species and processes were identified through discussions with EKZNW staff who had a thorough knowledge of KwaZulu-Natal's avifauna.

\section{Hydrological resources}

Mean annual runoffs (MAR) for quaternary catchments for KwaZulu-Natal and South Africa were obtained from Midgley et al. (1994). Data on 'virgin' vs. 'developed' incremental MAR (taking into account streamflow reduction activities which include, inter alia, forestry, alien vegetation and paved area) per quaternary catchment were also obtained from the Department of Water Affairs and Forestry (DWAF), based on simulations for the 1995 national hydrological base data (Strydom, 2006) using a risk-based hydrological model (Water Situation Assessment Model - WSAM) (Schultz and Watson, 2002). Water-yield zones were calculated for the province (see Appendix I), to illustrate areas of net runoff based on the difference between median monthly precipitation and crop evapotranspiration.

The total area of estuaries and wetlands, and length of rivers within KwaZulu-Natal, were calculated from the appropriate coverages listed (Table 1). All estuaries for the province have previously been delineated according to the $5 \mathrm{~m}$ contour line around each water body. The area of St. Lucia north of 'The Narrows', and the area south of the inlet to Third Lake (KuHlange) of the Kosi Lake system were classified as freshwater systems, and were excluded from the estuaries' coverage and added to the wetlands area. The area of freshwater lakes within the province, which are classified as a wetland category in the KwaZulu-Natal wetlands coverage, was also calculated, as these lakes represent a distinct biodiversity feature within the province. Wetlands now identified as dams were excluded from the calculated wetland area. A 1:500 000 river coverage from DWAF (2005) was used as the basis for river analyses, because this is the only river coverage currently available for South Africa for which stream orders have been assigned according to Strahler's (1964) stream classification system. The percentage of each feature falling within protected areas was also calculated, with only rivers protected on both sides of their river bank being included; rivers which fell within a $500 \mathrm{~m}$ buffer of a protected area boundary were excluded (after Nel et al., 2007). Using this method, rivers which flowed through long, thin protected area units less than $1000 \mathrm{~m}$ wide were excluded from the calculations.

River profiles, which enable freshwater geomorphologists and ecologists to define reach types, were derived for 9 mainstem rivers within KZN from the 1:500 000 river coverage. A $200 \mathrm{~m}$ DEM was overlaid by each of these arcs, to derive a profile using Idrisi's 'Profile' function (Clark Labs, 2003). Thus, at a resolution of $4 \mathrm{ha}$, and over a distance of $600 \mathrm{~km}$, altitudes were assigned for every $200 \mathrm{~m}$ of river length from sea to source. Because of the error between the DEM and the river arcs, these data were smoothed using a 15 pixel (or $3 \mathrm{~km}$ ) moving average.

The 1:500 000 scale river coverage was intersected with EKZNW's primary catchments coverage (which was derived from subcatchments delineated from a $90 \mathrm{~m}$ digital elevation model, and is similar to, but distinct from the primary catchments map developed by Midgley et al., 1994) coverage to calculate bifurcation ratios, drainage densities, and a simple discontinuity index (DI) for each primary catchment. The DI was 
calculated by dividing the river lengths within each primary catchment by the number of dams, to provide a conservative estimate of river network fragmentation within each primary catchment. It is acknowledged that these metrics change exponentially depending on the scale of maps used.

Free-flowing rivers were identified for KwaZulu-Natal based exclusively on a desktop exercise undertaken using Arcview 3.2 (ESRI 1999). Four coverages were used, viz.:

- Dams

- 1:500 000 rivers

- Primary catchments

- 1:50 000 topographic maps as a backdrop to verify the presence of in-stream impoundments in the dam coverage.

The primary catchments coverage was intersected with the river coverage to group rivers according to their respective primary catchments. That combination was then overlaid with the dams' coverage in combination with the 1:50 000 topographic map backdrops. Main-stem rivers, together with their tributaries, were assessed, and rivers that were free-flowing according to the WWF (2006) definition, were extracted from the existing river coverage.

Limited analyses of mean daily flow time series were undertaken for river systems where the time series could be divided into two (pre- and post-event) based on a known, dated event, such as construction of an impoundment. Time series were divided into two groups (pre- and post-impact) and analysed using non-parametric statistics (medians and percentiles) because of the typically skewed nature of hydrological data (TNC 2006). Analyses were undertaken using the 'Indicators of Hydrologic Alteration’ (IHA) software (TNC 2006), which outputs analyses as a range of metrics of ecological importance. Using this time series analysis software, it is possible to identify changes to flow patterns (frequency, magnitude, time and duration) using a 'range of [natural] variability' approach which sets upper and lower quartiles of what the 'natural' variability of a river system should be in terms of mean daily flows (Richter et al., 1996;1997).

\section{Results}

\section{Biological resources}

KwaZulu-Natal has a total of 75 species (including subspecies) (11 families) of amphibians, of which 6 are endemic to the province. Similarly, there are a total of 143 species (35 families) of fish (freshwater and diadromous species and subspecies) within the province, of which 4 are endemic to KwaZuluNatal. Ecologically, KwaZulu-Natal has been subdivided into 6 biogeographic regions (Goodman 2006, unpublished data) (Fig. 1). The number of species per biogeographic region, as well as number of endemic species for KwaZulu-Natal, are shown in Table 2. For both fish and amphibians, the Zululand biogeographic region displayed the highest species richness. Relative to fish and amphibians, aquatic macroinvertebrates have been poorly sampled, and little is known of their conservation status. Odonata are the best surveyed (63 species of Anisoptera and 1 endemic; 31 species of Zygoptera and 3 endemic), while data for the typically aquatic orders (Ephemeroptera, Trichoptera, Plecoptera and Megaloptera) are scarce.

KwaZulu-Natal has no avifauna wetland endemics (Wakelin, 2007). However, of the bird species which rely on freshwater systems as an integral part of their life histories, a number are red-listed and/or critically endangered wetland dependants;

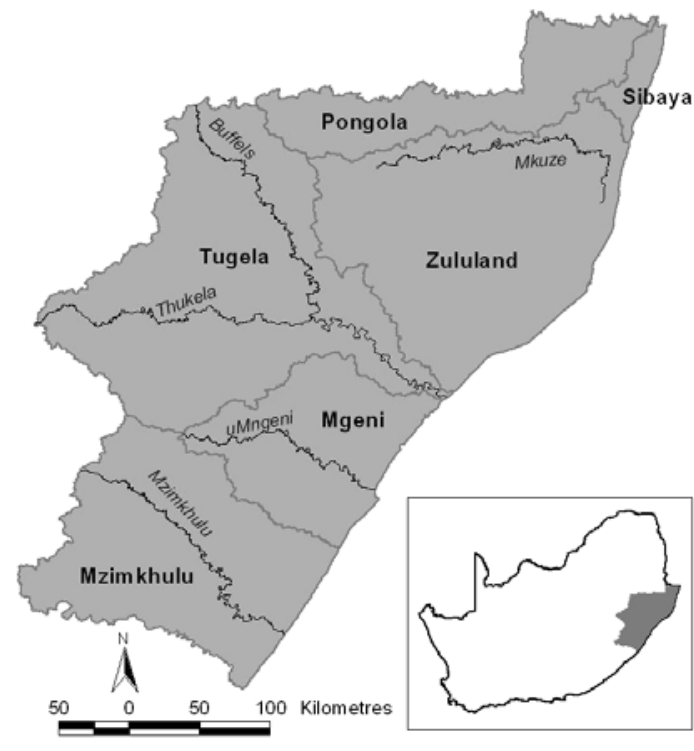

Figure 1

Major aquatic biogeographic regions of KwaZulu-Natal, with mainstem rivers for which profiles have been discussed in this analysis (see Fig. 3)

\begin{tabular}{|c|c|c|}
\hline \multicolumn{3}{|c|}{$\begin{array}{c}\text { TABLE } 2 \\
\text { Numbers of fish and amphibian species within } \\
\text { major biogeographic regions of KwaZulu-Natal, as } \\
\text { well as number of species endemic to KwaZulu-Natal }\end{array}$} \\
\hline $\begin{array}{l}\text { Biogeographic } \\
\text { region }\end{array}$ & $\begin{array}{l}\text { Fish (No. of spe- } \\
\text { cies/ No. of endemic } \\
\text { species) }\end{array}$ & $\begin{array}{l}\text { Amphibians (No. } \\
\text { of species/ No. of } \\
\text { endemic species) }\end{array}$ \\
\hline Pongola & $65 / 2$ & $26 / 0$ \\
\hline Sibaya & $50 / 1$ & $26 / 0$ \\
\hline Zululand & $91 / 3$ & $45 / 2$ \\
\hline Thukela & $48 / 3$ & $26 / 4$ \\
\hline uMngeni & $36 / 4$ & $37 / 3$ \\
\hline Mzimkhulu & $66 / 2$ & $27 / 4$ \\
\hline
\end{tabular}

a further category is wetland-dependent migratory species. In the former category, the blue swallow (Hirundo atrocaerulea) is critically endangered, and requires the grassland/wetland ecotone as necessary habitat (Wakelin, 2006). In the latter category are barn swallows (H. rustica) which, while being relatively common, are international migrants which roost in wetlands (Wakelin, 2007).

\section{Hydrological resources}

KwaZulu-Natal falls within the Eastern Escarpment drainage region of South Africa, and contains all or part of 4 of the 22 primary drainage regions in South Africa (Midgley et al., 1994). Out of a national total average MAR of $52000 \times 10^{6}$ $\mathrm{m}^{3} \cdot \mathrm{a}^{-1}$, approximately $28.5 \%$ (ca. $14800 \times 10^{6} \mathrm{~m}^{3} \mathrm{a}^{-1}$ ) is drained by the major river systems in KwaZulu-Natal province (Fig. 1). According to the WSAM analyses (Strydom, 2006), MAR values per quaternary catchment in KwaZulu-Natal have been reduced by $8.5 \pm 11.3 \%$ (mean $\pm \mathrm{SD}$ ), although these values range from $0 \%$ (un-impacted) to as high as $64 \%$. Critical water-yield areas are largely concentrated along the western escarpment (Fig. 2).

Major aquatic ecosystems sustaining the freshwater diversity of the province include 79 estuaries (ca. 30600 ha), 585000 


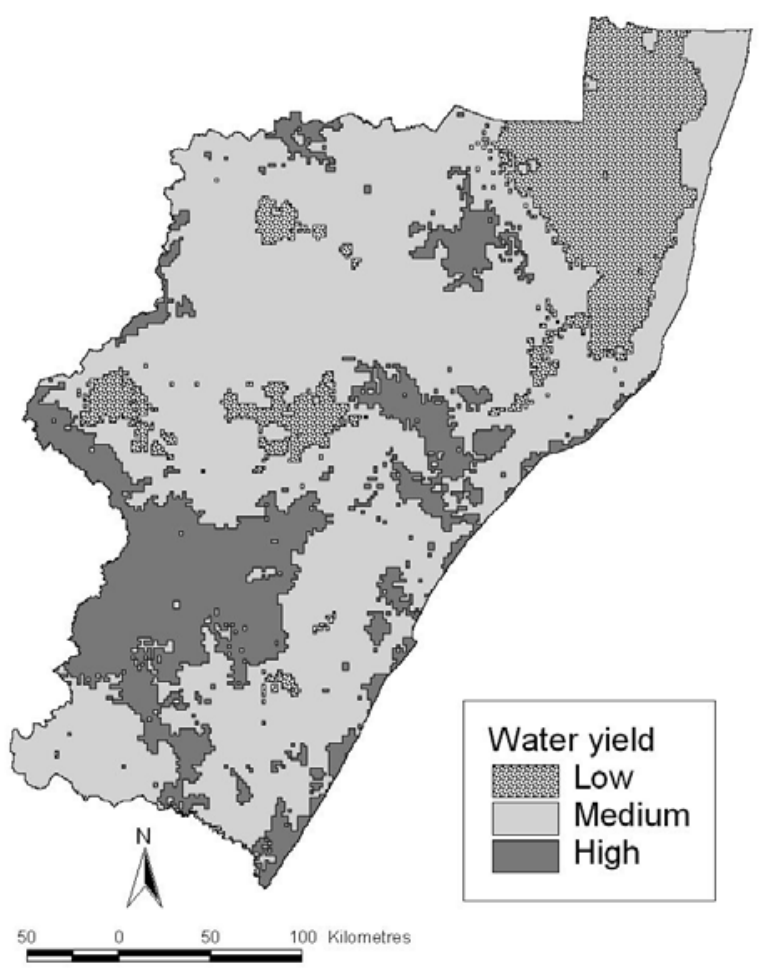

Figure 2

Water-yield map for KwaZulu-Natal, showing areas of high, medium and low water yield

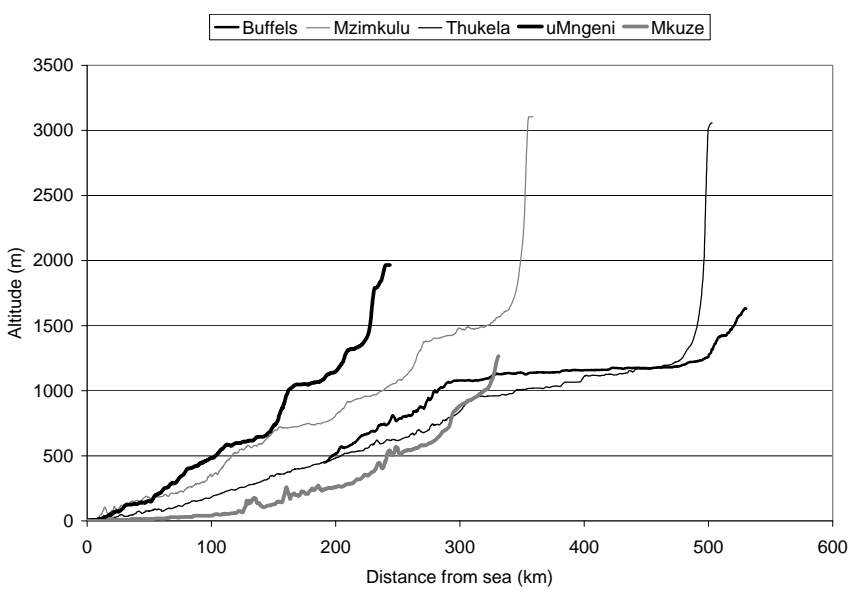

Figure 3

Selected river profiles for five major rivers within KwaZulu-Natal

ha of wetlands, and at least $18000 \mathrm{~km}$ of river (see Table 3). Of these areas, $17 \%$ and $41 \%$ of wetlands and estuaries respectively fall within protected areas. Fifteen of the 79 recognised estuaries fall within protected areas, to varying degrees. Included in the area of wetlands are at least 48500 ha of freshwater lakes and pans, particularly in the coastal region of the Zululand aquatic biogeographic region, all of which are considered to be important in maintaining freshwater biological diversity through their role in providing freshwater habitat and in maintaining regional freshwater aquifers. Of these, the larger freshwater lakes include

TABLE 3

River lengths (at three different scales) within KZN and within protected areas, and estimates of river lengths remaining free-flowing. Areas of estuaries and wetlands within KwaZulu-Natal, and falling within protected areas, are also provided

\begin{tabular}{|l|c|c|c|}
\hline System & Length $\mathbf{( k m ) / a r e a ~ ( h a ) ~}$ & $\begin{array}{c}\text { Length/area within } \\
\text { protected areas }\end{array}$ & $\begin{array}{c}\text { Total \% of system } \\
\text { 'protected' }\end{array}$ \\
\hline Rivers (1:500 000) & 18400 & $1000(1400)^{*}$ & $5.4(7.6)^{*}$ \\
\hline Rivers (1:250 000) & 4800 & N/A & N/A \\
\hline Rivers (1:50 000) & 197000 & N/A & 32.0 \\
\hline Free-flowing rivers (1:500 000) & 3000 & 970 & 17.0 \\
\hline Wetlands & 585000 & 100100 & 41.0 \\
\hline Estuaries & $30600(79)^{\#}$ & $12400(15)^{\#}$ & \\
\hline
\end{tabular}

* Values in brackets refer to all rivers associated with protected areas, while values outside parentheses reflect river lengths associated with protected areas but excluding rivers which form protected area boundaries;

*Values in brackets refer to numbers of estuaries.

\section{TABLE 4}

Number of river arcs, average length and total river length per stream order, based on the DWAF (2005) 1:500 000 river coverage. Average length and total length calculated to nearest kilometre and hundred kilometres respectively.

\begin{tabular}{|c|c|c|c|}
\hline Order & Count & Avg. length $\mathbf{( k m )}$ & Total length $\mathbf{( k m )}$ \\
\hline 1 & 340 & 31 & 10500 \\
\hline 2 & 89 & 47 & 4100 \\
\hline 3 & 25 & 92 & 2300 \\
\hline 4 & 8 & 154 & 1200 \\
\hline 5 & 1 & 316 & 300 \\
\hline Total & 463 & N/A & 18400 \\
\hline
\end{tabular}

Sibayi, Bhangazi North, Bhangazi South, Mgobozeleni; and aManzamnyama (Fourth Lake) and KuHlange (Third Lake) of the Kosi Lake system. Only $7.6 \%$ of KwaZulu-Natal's rivers (1:500 000 scale) fall within protected areas, although this value drops to $5.4 \%$ if rivers falling within $500 \mathrm{~m}$ of a Reserve boundary are excluded.

Main-stem river profiles each show distinct longitudinal patterns, although it is possible to generalise that KwaZulu-Natal's rivers typically exhibit a distinct escarpment zone, followed by flatter mid-slopes which steepen into eastern coastal zones (Fig. 3).

According to Strahler's (1964) stream order classification system, the Thukela River is the highest order river $\left(5^{\text {th }}\right)$ within the province. The number of rivers within the province decreases exponentially as stream order increases, while the average length of river per stream order increases exponentially with stream order (Table 4). Based on these data, the longest 


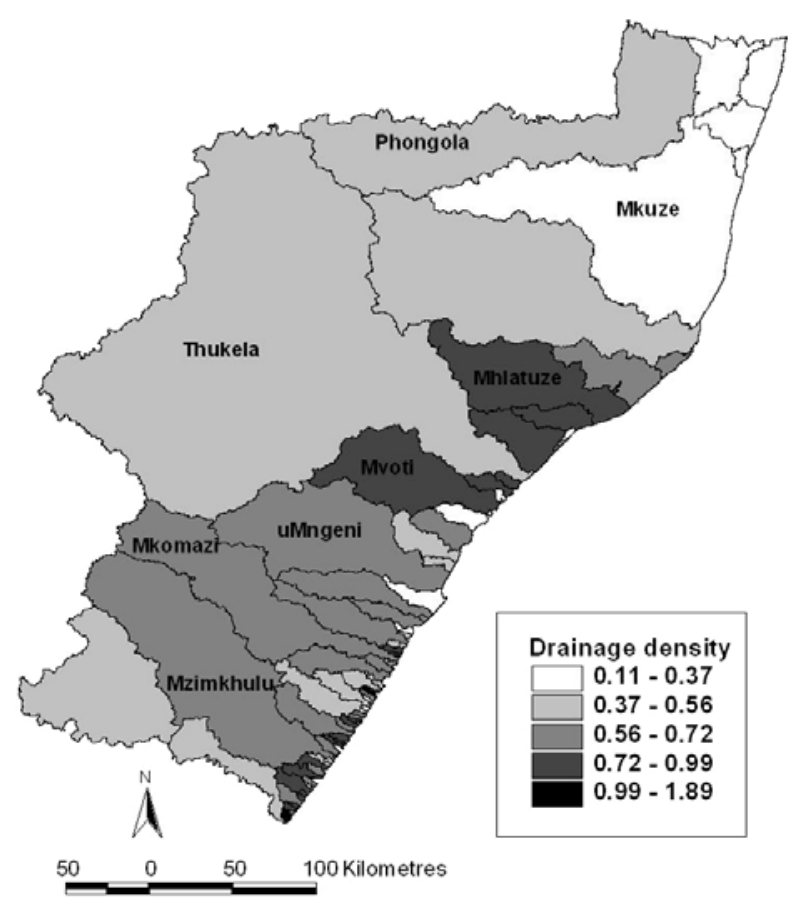

Figure 4

Drainage density of primary catchments within KwaZulu-Natal

river systems within KwaZulu-Natal, in addition to the Thukela, are the Phongolo, Buffels, Mzimkhulu Rivers, all of which are $4^{\text {th }}$ order streams. Based on these data, the bifurcation and stream length ratios for KwaZulu-Natal were calculated to be 3.19 and 1.20 respectively. At the 1:500 000 scale, drainage densities for each primary catchment ranged from 0.51 to $0.03 \mathrm{~km}$ of river per $\mathrm{km}^{2}$, with a mean density of $0.240 \mathrm{~km} \cdot \mathrm{km}^{-2}$ and an average coefficient of variation of $38.6 \%$. It was clear from a spatial representation of drainage densities that the Mvoti and Mhlatuze catchments had the highest drainage densities, with the southern Natal regions (Mzimkhulu, Mkomazi and uMngeni) also exhibiting relatively high drainage densities. Conversely, the northern coastal Zululand regions (Mkuze River region and Phongola catchment) showed the lowest drainage density (Fig. 4).

Within KwaZulu-Natal, 24 rivers are free-flowing (Fig. 5). This represents a total of $16 \%$ of KwaZulu-Natal's total river length which remains un-impounded from source to sea, based on 1st to 5th order stream lengths at a 1:500 000 scale. Only nine out of a total of 26 rivers (35\%) longer than $100 \mathrm{~km}$ remain free-flowing. Natural discontinuities ( $\geq 150$ waterfalls) within all river systems were excluded from analyses; artificial discontinuities to these river catchments (expressed as river length per dam) ranged from 0.3 to $40.8 \mathrm{~km}$, with the least continuous catchments being in southern Natal (Fig. 6). The Mzimkhulu (> 1119 dams), Thukela (> 672 dams) and Mkuze (> 85 dams) catchments were amongst the most impounded in the province, in spite of these catchments also containing free-flowing rivers (see Fig. 5).

Pre- and post-impact analyses were not possible for most of the rivers in KwaZulu-Natal, due to gauging weirs on many of the rivers only having been installed after completion of impoundments. Additionally, according to Taylor et al. (2003), analyses which show any meaningful trends should be based on at least 20 years of flow data, which reduced the flow analysis options further. One illustrative analysis was undertaken at the gauging weir at Howick (U2H001), downstream of Midmar Dam on

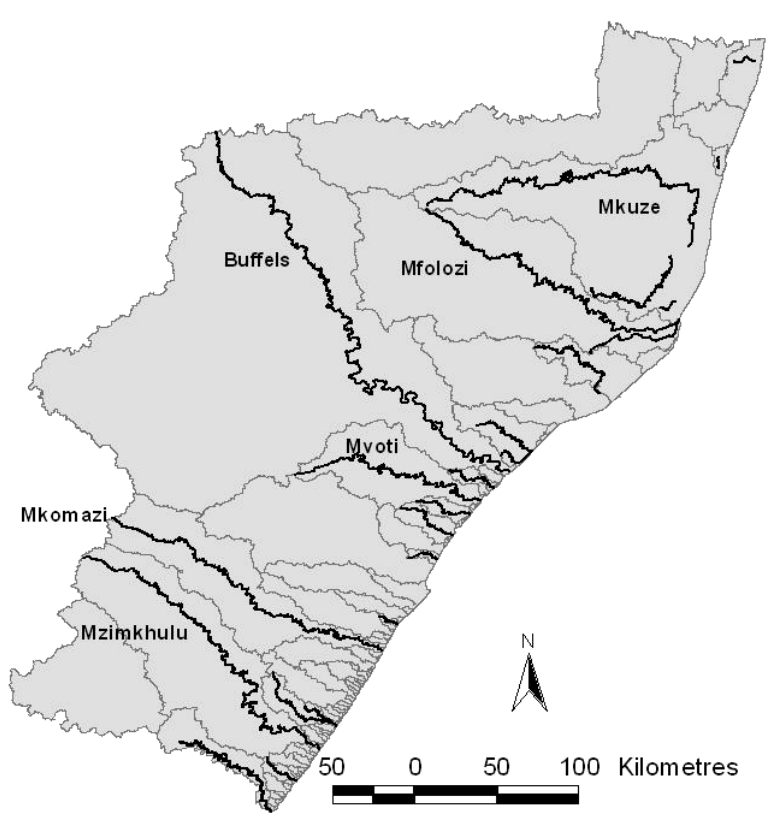

Figure 5

Free-flowing rivers within KwaZulu-Natal

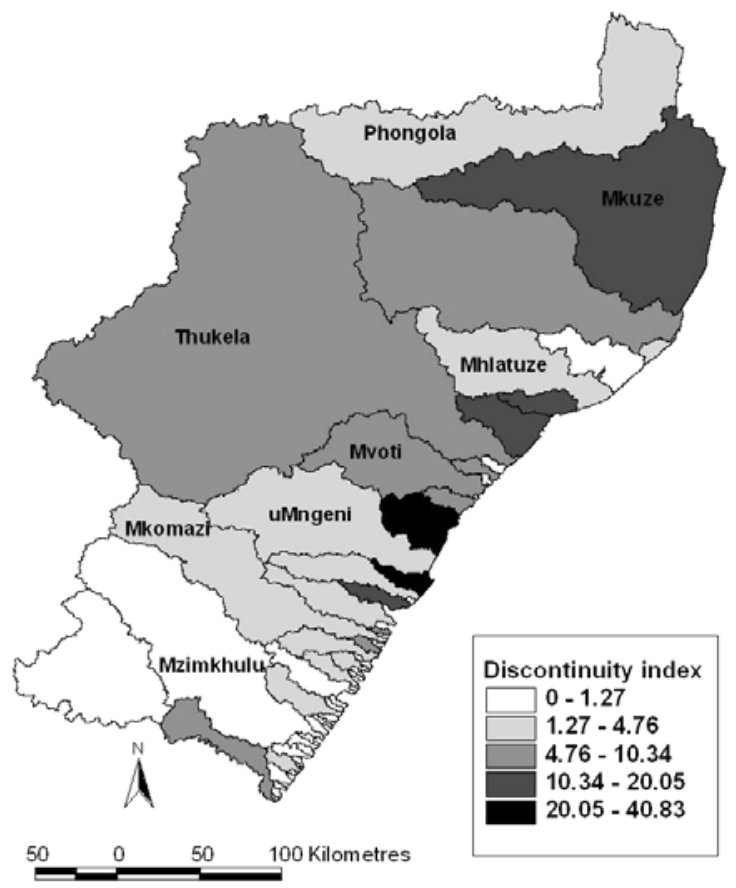

Figure 6

Discontinuity index for primary catchments within KwaZulu-Natal

the uMngeni River. Almost 40 years of mean daily flow rate data for this gauging weir are available (2 December 1948 to 31 December 1988), and this time series could be divided into two (1948-1963 and 1966-1988) based on when Midmar Dam began flooding upstream of this weir in 1963 (Little, 1996). While mean annual flows were similar for pre- and post-impoundment periods (5.61 vs. $5.34 \mathrm{~m}^{3} \cdot \mathrm{s}^{-1}$ ), changes to the flow signatures emerged based on selected ecologically significant metrics (Table 5; Fig. 7). The upstream impoundment at Midmar Dam has resulted in reduced seasonality of flows (Parameter Group 1 - reduced seasonal magnitudes) as well as changes in extreme flows -2 months later for the annual $1 \mathrm{~d}$ minimum, and 2 months 


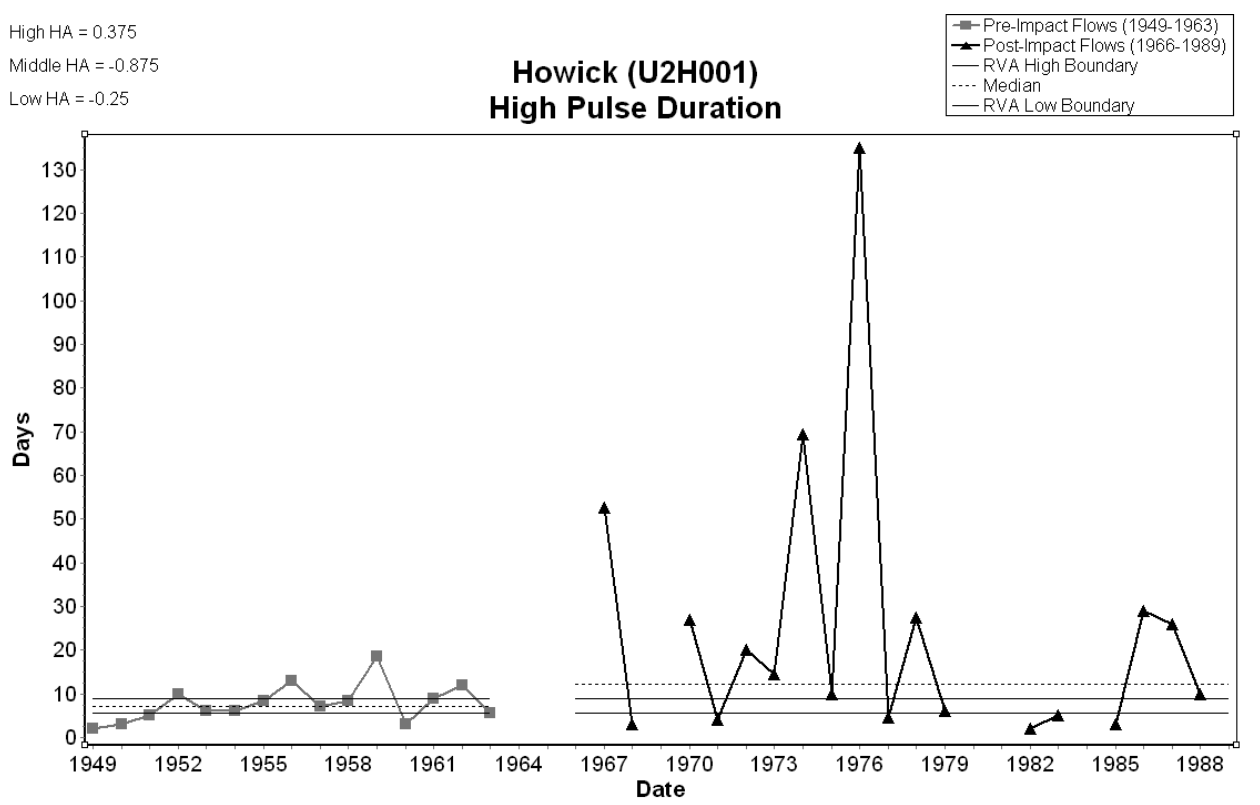

Figure 7

Changes to the lengths of pre- and post-impoundment high pulse durations for the uMngeni River at gauging weir U2H001. The RVA low and high boundaries refer to the $33^{\text {rd }}$ and $67^{\text {th }}$ percentiles respectively. premature for the 1d maximum. While flows have also become more regulated, system predictability has been reduced through the impoundment, as reflected in the reduced seasonality and Colwell's (1974) predictability values (Table 5). One other illustrative example in the change to flow signatures is reflected in the pre- and post-impoundment comparison of high pulse durations, which were graphed to also show the 'natural range of variability' developed by Richter et al. (1997) (Fig. 7). In this analysis, observed frequencies are compared with expected frequencies of the same events, to calculate a hydrological alteration factor (TNC 2006); in this case the number of high pulses has increased, while the numbers of middle and low pulses have decreased.

\section{Discussion and conclusions}

The current drainage network in KwaZulu-Natal is relatively recent, by global geological standards, having developed within the last 5.1 million years, during the Pliocene epoch of the Cenozoic, primarily in response to geological uplift events (Partridge and Maud, 2000). This led to isolated headlands, typically deeply incised river valleys, and few coastal floodplain systems, as is illustrated by the river profiles. These uplift events are reflected in the numerous waterfalls within the province, as well as occasional thermal hot springs, which are likely to exhibit unique aquatic biological diversity due to raised water temperatures.

Biological consequences of this geological history include individual river systems which are typically fairly isolated from each other, yet which are also relatively depauperate in endemic fish species. Because of their age, and links to the ancient Orange River basin (Skelton, 1986), the river systems in KwaZulu-Natal are likely to show distinct biological similarities with the parent stock from the Orange River drainage basin (Skelton, 1986), and also lower levels of endemism relative to older systems. While the Sabie-Sand River system is the most species-rich in terms of fish in South Africa (45 indigenous and 4 alien species of fish - Weeks et al., 1996), the combined fish species diversity of the various biogeographic regions in KwaZulu-Natal nevertheless amounts to at least 143 species and subspecies of fish. In spite of low endemism in fish and amphibian species, community structure based on combinations of 75 species of amphibians

\begin{tabular}{|l|c|c|}
\hline \multicolumn{3}{|c|}{$\begin{array}{c}\text { TABLE 5 } \\
\text { Pre- and post-impoundment statistics for mean } \\
\text { daily rates at gauging weir U2H001 on the } \\
\text { uMngeni River, based on IHA outputs }\end{array}$} \\
\hline Statistic & $\begin{array}{c}\text { Pre- } \\
\text { impoundment }\end{array}$ & $\begin{array}{c}\text { Post- } \\
\text { impoundment }\end{array}$ \\
\hline Colwell's Predictability & 0.53 & 0.43 \\
\hline Parameter Group 1 & & \\
\hline October & 1.28 & 1.89 \\
\hline November & 2.75 & 1.58 \\
\hline December & 5.70 & 1.77 \\
\hline January & 6.92 & 3.26 \\
\hline February & 8.20 & 4.56 \\
\hline March & 7.65 & 5.69 \\
\hline April & 4.68 & 4.03 \\
\hline May & 3.42 & 1.76 \\
\hline June & 2.19 & 1.67 \\
\hline July & 1.71 & 1.59 \\
\hline August & 1.30 & 1.84 \\
\hline September & 1.29 & 1.70 \\
\hline Parameter Group 3 & & \\
\hline (Julian) Date of annual & 274.00 & 339.50 \\
1-day minimum & & 326.50 \\
\hline (Julian) Date of annual & 30.00 & \\
1-day maximum & & \\
\hline
\end{tabular}

*Refers to IHA parameter Group 1 (Magnitude of monthly water conditions - monthly median flows) as defined by Richter et al. (1996). This group includes ecosystem influences such as habitat availability and influences on water temperature.

${ }^{\#}$ Refers to IHA parameter Group 3 (Timing of annual extreme water conditions) as defined by Richter et al. (1996). This group includes ecosystem influences such as spawning cues for migratory fish.

and 143 species of fish are likely to provide the province with unique freshwater diversity assets. The lack of data on aquatic macroinvertebrates highlights both a priority to collect and describe aquatic invertebrate communities, at least of the different aquatic biogeographic regions, but also highlights the need for an aquatic conservation plan. Schael and King (2005) have shown that rivers in the Western Cape can be separated based on 
unique signatures determined by aquatic invertebrate communities. Knowledge of aquatic macroinvertebrates at species level for rivers in KwaZulu-Natal may thus assist in a biotic classification of river types. Additionally, because of the importance of KwaZulu-Natal as a water-yield area within South Africa, it is of critical importance to recognise the conservation value of these rivers, central to which is conserving their biological diversity.

Threats to freshwater biodiversity include processes and activities which reduce system persistence, and alter community diversity and patterns including reduced genetic diversity. One such threat to biological process could be the loss of migratory bird species due to loss of wetland habitat. With South Africa being a later signatory to the Convention on the Conservation of Migratory Species of Wild Animals (CMS or Bonn Convention of 1979), there is an international obligation to maintain these habitats to preserve this biological process. Threats also include changes to flow patterns, which were illustrated using the analyses on the gauging weir on the uMngeni River near Howick, where superficially flows remain the same. However, changes to flow patterns result in changes in the timing, duration, magnitude and frequency and high and low flow events. This in turn impacts on, inter alia, water chemistry and water temperatures. The combined effect of these changes is likely to alter cues for migrations and life history events (spawning and emergence) (Richter et al., 1997). Within South Africa, the primary threats to freshwater systems are regarded as being river regulation, followed by catchment transformation (Davies et al., 1993). Similar threats are recognised worldwide (Stein et al., 2002; Allan 2004), with links between catchment transformation and river degradation being increasingly recognised (Allan, 2004). Anticipated threats, which conservation planning should take cognisance of, are climate change, and associated increases in water temperatures. Seasonal flow and water temperature signatures provide temporally tiered niches which allow diverse aquatic invertebrate species complexes to coexist (see, for example, Vannote and Sweeney (1980); Bogan and Lytle (2007)). River regulation essentially flattens the temporal habitat template, and is likely to lead to reduced species diversity and simplified species communities which are less resilient. According to Rivers-Moore et al. (2007), the best management option in this regard is maintaining the river's ability to adapt to change, by managing for continuity. This would also necessitate further refining the discontinuity index used in this study. Some of the most discontinuous catchments in KwaZulu-Natal (for example, Mzimkhulu) also contain free-flowing rivers, because the current DI is based on the number of dams throughout the entire primary catchment as a function of total catchment river length, rather than un-impounded main-stem river length. Thus within any conservation plan, the identification of free-flowing rivers is a critical step. Such an initiative is in line with recent global developments in freshwater conservation planning (WWF, 2006). Additional threats include homogenisation of genetic diversity through inter-basin transfers of samespecies. Changes in hydrological and thermal time series (i.e. abiotic river signatures) are more subtle forms of river degradation which alter community patterns by affecting abiotic cues.

Statistical descriptions of river networks, including drainage density and bifurcation ratios, provide a useful starting point for generating testable hypotheses for further eco-hydrological research (for example, correlations between species diversity and drainage density). Thus, according to Strahler (1964), bifurcation values typically lie between 3 and 5 . KwaZulu-Natal's bifurcation ratio of 3.19 is thus not exceptional by global comparison. However, since calculations were based on 1:500 000 scale river coverage, this ratio cannot be seen as definitive, and may change with increasing scale. According to these ratios, the logarithm of the number of stream channels increases by a factor of 3.19 with decreasing stream order, and the logarithm of stream lengths increases by a factor of 1.20 with an increase in stream order. In all of these cases, it is essential to develop scaling relationships, if GIS analyses of river coverages are to be undertaken with any degree of confidence. Other important research questions to be answered are firstly whether areas of highest aquatic species richness relate to areas of highest drainage density, or whether there is a correlation between species diversity and catchment area; and secondly, whether species diversity is higher around nodes of rapid abiotic change (aquatic ecotones) such as waterfalls and confluences. Assuming these trends to be significant, answers to such questions could be used to predict expected aquatic species richness relative to catchment disturbance indices.

Successful protection of KwaZulu-Natal's freshwater resources requires a systematic approach, developed in tandem with existing terrestrial conservation plans. Regional conservation authorities such as Ezemvelo KwaZulu-Natal Wildlife are legally mandated to develop conservation plans. This process includes developing a classification of river types, identifying gaps in the existing protected areas network, and setting conservation targets (i.e. how much of each type should be conserved) (Margules and Pressey, 2000). The final product identifies specific areas which require active conservation, and is used in a public participation process to negotiate land tenure (Groves, 2003). Such a plan provides freshwater conservation planners with a broader context in which to balance vulnerability vs. irreplaceability when determining which aquatic features to protect, as outlined by Margules and Pressey (2000). Within this approach, there should be provision for iterative revisions of the plan, as data and knowledge improve with time.

Conservation plans ultimately aim to identify areas (for example, wetlands) or river segments which are irreplaceable and/ or representative of freshwater diversity within the province and thus require protection. Plans should be based on a defendable freshwater classification - owing to data limitations South African conservation planners generally apply a top-down classification process, which is hierarchical and assumes sensitivity to scale and process by breaking the region of interest down into biologically similar ecoregions (Eekhout et al., 1997; Higgins et al., 2005). The final conservation plan is then derived through a process of defining planning units (which set the resolution of the conservation plan), which are attributed with biodiversity features considered to be of importance (river types, species, wetland types, estuary types), with conservation targets being set for each feature (Smith et al., 2006). 'Costs' of adding planning units to a conservation portfolio are also incorporated into the process, so that certain units can be selected above others based on least-cost weightings. Such costs may be defined in a number of ways, and how these are defined affects how planning units are selected. For example, costs may be based on perimeter lengths of planning unit portfolios, penalty costs for not meeting targets (Smith et al., 2006), as well as metrics combining, inter alia, the presence of free-flowing rivers, catchment transformation, and areas with high surface water yield. Applying a cost surface based on socio-economic costs and benefits is a further research option which is currently being explored (e.g. Wilson et al., 2006).

Freshwater conservation plans pose particular conceptual problems to conservation planners because of the close relationship between freshwater systems and upstream-downstream 
catchment conditions (O’Keeffe et al., 1987). For example, since rivers and estuaries typically assimilate what is happening within the catchment (Allan, 2004), estuaries can only be seen to be truly protected if their rivers upstream, and their catchments, are 'healthy'. Similarly, a river which flows through a protected area cannot be assumed to be protected.

Critical issues in the conservation planning process are the availability and quality of the data, and the need for intelligent application of the results from GIS analyses. For example, conservation targets for biodiversity features should ideally combine number of occurrences and areas of biodiversity features, to avoid being skewed by single, large areas of a feature type. Other considerations are the application of data at appropriate scales - data at too fine a scale may require a large amount of processing time and effort, when data at a coarser scale could provide insights leading to the same management decision at half the effort. Conversely, data at too coarse a scale could overemphasise certain features within the conservation plan at the expense of other features. Conservation plans are also defined largely by the features selected as inputs, and how targets are chosen for these. Among such features are the species chosen as umbrella species (Groves, 2003). This process can also have undue leverage in affecting the final conservation plans, based on how the species have been selected (endemic vs. rare vs. threatened), the quality of the species database, and how the species' expected distributional ranges have been modelled.

KZN Wildlife is currently developing a hierarchical river type classification, to which initial conservation targets will be applied based on length of each river type. Current research priorities include investigating objective methods of setting freshwater conservation targets, as well as developing a list of appropriate freshwater 'umbrella' species, whose distribution ranges will need to be modelled. A final critical research priority is developing a more objective means of deriving conservation targets for freshwater systems (sensu Margules and Pressey, 2000). Currently, freshwater conservation targets are based on an arbitrary $20 \%$ value, which stems from a recommendation by the IUCN (Roux et al., 2006).

\section{Acknowledgements}

We thank support staff at EKZNW for assistance with coverages: Petros Ngwneya; Anneita Ramkussen, Daveshni Padayachee; and Heidi Snyman (WRC). James Wakelin (EKZNW) is thanked for commenting on the avifauna of KwaZulu-Natal. The reviewers are thanked for their inputs and constructive criticisms.

\section{References}

ALCAMO J and HENRICHS T (2002) Critical regions: A model-based estimation of world water resources sensitive to global changes. Aquat. Sci. 64 352-362.

ALCAMO J, DÖLL P, HENRICHS T, KASPAR F, LEHNER B, RÖSCH $\mathrm{T}$ and SIEBERT S (2003) Global assessments of water withdrawals and availability under current and future 'business-as-usual' conditions. Hydrol. Sci. J. 48 339-348.

ALLAN JD (2004) Landscapes and riverscapes: The influence of land use on stream ecosystems. Annu. Rev. Ecol. Evol. Syst 35 257-284.

BOGAN MT and LYTLE DA (2007) Seasonal flow variation allows 'time-sharing' by disparate aquatic insect communities in montane desert streams. Freshwater Biol. 52 290-304.

CHIEF DIRECTORATE: SURVEYS AND MAPPING, Private Bag X10, Mowbray, 7705, South Africa.

CLARK LABS (1999) Cartalinx v. 1.2. Clark Labs, Clark University, Worcester, MA, USA. http://www.clarklabs.org .
CLARK LABS (2003) Idrisi Kilamanjaro Edition. Clark Labs, Clark University, Worcester, MA, USA. http://www.clarklabs.org

COLWELL RK (1974) Predictability, constancy and contingency, of periodic phenomena. Ecol. 55 1148-1153.

COMPUTAMAPS (2001) Private Bag X20, Constantia 7848, South Africa.

DAVIES BR, O’KEEFFE JH and SNADDON CD (1993) A Synthesis of the Ecological Functioning, Conservation and Management of South African River Ecosystems. WRC Report No. TT 62/93. Water Research Commission, Pretoria, South Africa.

DEPARTMENT OF ENVIRONMENTAL AFFAIRS AND TOURISM (DEAT) (2005) South Africa's National Biodiversity Strategy and Action Plan. DEAT, Pretoria, South Africa.

DEPARTMENT OF WATER AFFAIRS AND FORESTRY (DWAF) (2005) Institute for Water Quality Studies, Private Bag X313, Pretoria, 0001

DRIVER A, MAZE K, ROUGET M, LOMBARD AT, NEL J, TURPIE JK, COWLING RM, DESMET P, GOODMAN P, HARRIS J, JONAS Z, REYERS B, SINK K and STRAUSS T (2005) National Spatial Biodiversity Assessment 2004: Priorities for biodiversity conservation in South Africa. Strelitzia 17. South African National Biodiversity Institute, Pretoria.

EEKHOUT S, KING JM, and WACKERNAGEL A (1997) Classification of South African Rivers. Volume 1. Department of Environmental Affairs and Tourism, Pretoria, South Africa.

ENVIRONMENTAL SYSTEMS RESEARCH INSTITUTE (1999) ArcView v. 3.2 Redlands, California, USA.

EZEMVELO KZN WILDLIFE (2001) Estuaries coverage, dataset i.d. 83. PO Box 13053, Cascades, 3202, South Africa.

EZEMVELO KZN WILDLIFE (2002) Wetlands coverage, dataset i.d. 569. PO Box 13053, Cascades, 3202, South Africa.

EZEMVELO KZN WILDLIFE (2007) Protected areas coverage, dataset i.d. 1031. POBox 13053, Cascades, 3202, South Africa.

GOODMAN PS (2006) Personal communication. Ezemvelo KZN Wildlife, PO Box 13053, Cascades, 3202, South Africa.

GROVES CR (2003) Drafting a Conservation Blueprint: A Practitioner's Guide to Planning for Biodiversity. The Nature Conservancy, Island Press, Washington, USA.

HIGGINS JV, BRYER MT, KHOURY ML and FITZHUGH TW (2004) A freshwater classification approach for biodiversity conservation planning. Conserv. Biol. 19 432-445.

LITTLE AM (1996) A Review of the 1970 Policy Relating to the Controlled Area of Midmar: Report on Policy Framework. Institute of Natural Resources Investigational Report No. 134, University of Natal, Pietermaritzburg, South Africa.

MARGULES CR AND PRESSEY RJ (2000) Systematic conservation planning. Nature 405 243-253.

MILLENNIUM ECOSYSTEM ASSESSMENT (2005a) Ecosystems and Human Well-Being: Wetlands and Water Synthesis. World Resources Institute, Washington, DC.

MILLENNIUM ECOSYSTEM ASSESSMENT (2005b) Ecosystems and Human Well-Being: Biodiversity Synthesis. World Resources Institute, Washington, DC,

MIDGLEY DC, PITMAN WV and MIDDLETON BJ (1994) Surface Water Resources of South Africa 1990. Vol. VI Appendices. WRC Report No. 298/6.1/94. Water Research Commission, Pretoria.

NEL JL, ROUX DJ, MAREE G, KLEYNHANS CJ, MOOLMAN J, REYERS B, ROUGET M and COWLING RM (2007) Rivers in peril inside and outside protected areas: a systematic approach to conservation assessment of river ecosystems. Diversity and Distributions 13 341-352.

O'KEEFFE JH, DANILEWITZ DB and BRADSHAW JA (1987) An 'expert system' approach to the assessment of the conservation status of rivers. Biol. Conserv. 40 69-84.

PARTRIDGE TC and MAUD RR (2000) Macro-scale geomorphic evolution of southern Africa. In: The Cenozoic of Southern Africa. Oxford University Press, Oxford. 3-18.

RICHTER BD, BAUMGARTNER JV, POWELL J and BRAUN DP (1996) A method for assessing hydrologic alteration within ecosystems. Conserv. Biol. 10 (4) 1163-1174.

RICHTER BD, BAUMGARTNER JV, WIGINGTON R and BRAUN 
DP (1997) How much water does a river need? Freshwater Biol. 37 231-249.

RIVERS-MOORE NA and JEWITT GPW (2007) Adaptive management and water temperature variability within South African rivers: What are the management options? J. Environ. Manage. 82 (1) 39-50.

ROUX DJ, NEL JL, MACKAY HM and ASHTON PJ (2006) Discussion paper on Cross-Sector Policy Objectives for Conserving South Africa's Inland Water Biodiversity. WRC Report No. TT 276/06. Water Research Commission, Pretoria, South Africa.

SCHAEL DM and KING JM (2005) Western Cape River and Catchment Signatures. WRC Report No. 1303/1/05. Water Research Commission, Pretoria, South Africa.

SCHULTZ CB and WATSON MD (2002) Water Situation Assessment Model: A Decision Support System for Reconnaissance-Level Planning, Theoretical Guide. Vol. 3. DWAF, Pretoria.

SCHULZE RE (1982) Agrohydrology and Climatology of Natal. ACRU Report No. 14, Department of Agricultural Engineering, University of Natal, Pietermaritzburg, South Africa.

SCHULZE RE (ed.) (2006) South African Atlas of Climatology and Agrohydrology. Water Research Commission, Pretoria, South Africa.

SKELTON PH (1986) Distribution patterns and biogeography of nontropical southern African freshwater fishes. In: Van Zinderen Bakker EM (Sr.), Coetzee JA and Scott L (eds.) Palaeoecology of Africa and the Surrounding Islands. Vol. 17 - Southern African Society for Quaternary Research: Proc. of the VIIth Bienn. Conf. 29 March-3 April 1985, University of Stellenbosch. AA Balkema, Rotterdam. 211-230.

SMITH RJ, GOODMAN PS and MATTHEWS WS (2006) Systematic conservation planning: a review of perceived limitations and an illustration of the benefits, using a case study from Maputaland, South Africa. Oryx 40 400-410.

STEIN JL, STEIN JA and NIX HA (2002) Spatial analysis of anthropogenic river disturbance at regional and continental scales: identify- ing the wild rivers of Australia. Landscape and Urban Planning 60 $1-25$

STRAHLER AN (1964) Quantitative geomorphology of drainage basins and channel networks, section 4-II. In: VT Chow (ed.) Handbook of Applied Hydrology. McGraw-Hill, New York. 4-39 - 4-76.

STRYDOM C (2006) Personal communication. Isifundi Consultants, Moreletta Park, Pretoria, 0044. <http://www.isifundi.co.za >

TAYLOR V, SCHULZE R and JEWITT G (2003) Application of the Indicators of Hydrological Alteration method to the Mkomazi River, KwaZulu-Natal, South Africa. Afr. J. Aquat. Sci. 28 1-11.

VANNOTE RL and SWEENEY BW (1980) Geographic analysis of thermal equilibria: A conceptual model for evaluating the effect of natural and modified thermal regimes on aquatic insect communities. Am. Nat. 115 667-695.

THE NATURE CONSERVANCY (2006) Indicators of Hydrologic Alteration. Version 7 User's Manual. http://www.nature.org/initiatives/freshwater/conservationtools (Accessed 27 November 2006).

WAKELIN JEA (2006) An investigation to determine the critical habitat requirements of the breeding Blue Swallow Hirundo atrocaerulea Sundevall. University of KwaZulu-Natal. Unpublished Masters thesis, Pietermaritzburg.

WAKELIN JEA (2007) Personal communication. Ezemvelo KZN Wildlife, PO Box 13053, Cascades 3202, South Africa.

WEEKS DC, O'KEEFFE JH, FOURIE A and DAVIES BR (1996) A Pre-Impoundment Study of the Sabie-Sand River System, Mpumalanga, with Special Reference to Predicted Impacts on the Kruger National Park. Vol. I: The Ecological Status of the Sabie-Sand River System. WRC Report No. 294/1/96. Water Research Commission, Pretoria, South Africa.

WILSON KA, McBRIDE MF, BODE M and POSSINGHAM H (2006) Prioritizing global conservation efforts. Nature 440 337-340.

WORLD WIDE FUND FOR NATURE (WWF) (2006) Free-flowing rivers: Economic luxury or ecological necessity? WWF Global Freshwater Programme, Netherlands http://assets.panda.org/downloads/freeflowingriversreport.pdf. Accessed on 27 November 2006).

\section{APPENDIX: Water-yield zones}

A water-yield map for KwaZulu-Natal was calculated based on the assumption that water yield is a function of the difference between precipitation and crop evapotranspiration. Raster images of monthly average evapotranspiration and monthly median rainfall for KwaZulu-Natal were obtained from the South African Atlas for Agro-Hydrology (Schulze, 2006), and converted to $200 \mathrm{~m}$ resolution raster images in Idrisi (Clark Labs, 2003) format. Monthly evapotranspiration values were subtracted from monthly median rainfall values, to provide twelve water-yield images for KwaZulu-Natal. By taking the three highest months of precipitation for each of the 21 rainfall regions as defined by Schulze (1982), December to March were selected as the most important water-yield months for KwaZulu-Natal.
The water-yield images for these months were added together to derive a quantitative summer water-yield image showing the net water yields for the province. Winter months were excluded because in these images, values across the province were similar and the images became too homogeneous. This net water-yield image was reclassified to represent regions of high, medium and low water yield: High $=$ all values $>0 \mathrm{~mm}$ (positive water yield); Medium = all water-yield values $<0 \mathrm{~mm}$ and $>$ coverage mean and one standard deviation $(-165 \mathrm{~mm}=-65$ minus 100) as derived from the frequency histogram from the net water-yield image; and Low $=$ all values $<-165 \mathrm{~mm}$ (mean minus one standard deviation). 
Available on website http://www.wrc.org.za ISSN 0378-4738 = Water SA Vol. 33 No. 5 October 2007 ISSN $1816-7950=$ Water SA (on-line) 